\title{
Design and Analysis of Solar Energy Mini-Grid for Rural Electrification
}

\author{
Michael Juma Saulo, Victor Odhiambo Omondi \\ Department of Electrical and Electronics Engineering, Technical University of Mombasa, Mombasa, Kenya \\ Email: michaelsaulo@yahoo.com, cneave73@yahoo.com
}

Received 7 September 2015; accepted 22 September 2015; published 28 September 2015

Copyright (C) 2015 by authors and OALib.

This work is licensed under the Creative Commons Attribution International License (CC BY). http://creativecommons.org/licenses/by/4.0/

(c) (i) Open Access

\section{Abstract}

Electric power is a key driver of economic growth and prosperity. But access to electricity still remains a distant dream for majority of the population living in the remote and arid areas of developing countries mostly sub-Saharan Africa. With the growing demand for safe and reliable energy, solar as a source of energy remains the least utilized energy source in the Kenyan economy and yet one of the safest forms of energy. Solar photovoltaic (PV) systems have shown their potential in rural electrification projects around the world. A solar based mini-grid is a solar PV (photovoltaic) plant with a localized distribution network to a unit village, or a cluster of villages, providing alternating current (AC). Basically it consists of solar PV modules of a certain capacity, solar inverters for converting the D.C power to AC power, housing for the battery bank and plant control systems. In areas where there is no grid connection or where diesel generation is the main power source, PV plants are able to generate electricity efficiently and relatively cheap. This paper was aimed at developing a standard procedure for the design and analysis of a mini-grid connected solar PV systems using PV modules connected in an array field. The standard procedure developed was validated in the design of a 20 kVA mini-grid-connected solar PV system for Nanyuki town in Laikipia County, Kenya. The analysis and evaluation of the load capacity requirements for the solar mini-grid were done. Data collected from SWERA were compared with the local load requirements. Optimization of the load versus production capacity of the solar system was carried out. The results showed that a mini-grid system of $20 \mathrm{kVA}$ might be developed at a capital cost of US\$ 56,000 to cater for $\mathbf{8 4 0 0}$ households including a school and dispensary. Analyses of the simulation results show that the project when implemented will supply about $61 \mathrm{KW} \cdot \mathrm{h}$ electricity per day or 22.2 MWh annually, which is about $15 \%$ of Nanyuki's annual electricity consumption. The project also stands the chance of saving about 200 tonnes of $\mathrm{CO}_{2}$ which will have been emitted by a crude oil fired thermal power plant generating the same amount of electricity. At the prevailing tariff conditions in the country, this project can be considered as financially viable with feed-in tariff scheme or other incentives such as grants/capital subsidies when applied. However, the other non-financial benefits like the greenhouse gas emissions savings can, in the long run, help mitigate the adverse effects of the climate change problem plaguing the entire earth. 


\title{
Keywords
}

\section{Mini-Grid, Photovoltaic (PV), Rural Electrification Program, SWERA}

\author{
Subject Area: Electric Engineering
}

\section{Introduction}

Electric power is a key driver of economic growth and prosperity. But access to electricity still remains a distant dream for majority of the population living in the remote and arid areas of developing countries. With the growing demand for safe and reliable energy, solar as a source of energy remains the least utilized energy source in the Kenyan economy and yet one of the safest forms of energy.

In 2010 the average rural energy consumption in Kenya stood at $1764 \mathrm{KW} \cdot \mathrm{h}$ with 164,133 customers connected to the main grid. This in turn gave an annual consumption of $290 \mathrm{GWh}$ [1]. It is estimated that 200,000 photovoltaic solar home systems, most of which are rated between $10 \mathrm{We}$ and $20 \mathrm{We}$ estimated at a cost of US\$100/We, are currently in use in Kenya and generate $9 \mathrm{GWh}$ of electricity annually [1]. Kenya has great potential for the use of solar energy throughout the year. A current rural population of 4 million households in Kenya alone clearly shows that there is a lot to be done with regard to rural electrification so as to cover up the wide gap between the supplied households and the growing rural population. There is significant potential for solar energy to be exploited in most parts of Kenya which experience up to over 6 hours of direct sunlight a day. Substantial research has been done over the years on exploiting the huge solar energy resource [2] [3].

In Kenya, only $1.2 \%$ of the households utilize individual solar PV panels for smaller loads, i.e. lighting and powering TV sets and radios. But most of these are stand-alone PV installations. Photovoltaic panels have shown its potential as a technology for decentralized rural electrification and as a means to improve access to electricity in rural areas of developing countries.

Over the last 3 years, the number of home systems installed has grown at an average of 20,000 units per annum and demand projected to reach 22 GWh annually in the year 2020 [4]. Given that there are 4 million households in rural Kenya alone, the demand for power has grown tremendously by the day.

Photovoltaic (PV) systems are composed of interconnected components designed to accomplish specific goals, ranging from powering a small device to feeding electricity into the main distribution grid. More specifically, PV devices convert sunlight into DC electricity. Such energy is transferred to the load or to the utility grid by means of a subsystem [5].

There are two main classifications:

1) Stand-alone systems;

2) Grid connected systems.

The main distinguishing factor between these two categories is that in stand-alone systems the solar energy output is matched with the load demand. When a PV system is interconnected with the main grid, it may deliver excess energy to the grid or use the grid as a backup system, in case of insufficient photovoltaic generation. Stand-alone systems are mostly used in the cases of rural electrification [6].

Currently Kenya generates a total of $1633 \mathrm{MW}$ of power from various sources. The peak demand however stands at $1780 \mathrm{MW}$ with numerous efforts being made to meet this rising demand [1] [4]. The core of these demands is the need for energy generation sources that are environmental friendly, reliable and efficient at the same time. This narrows down to solar and wind energy sources. This paper proposes a base study of Laikipia County precisely focusing on Nanyuki area. It experiences direct normal irradiance levels of $5 \mathrm{KW} / \mathrm{m}^{2}$ and has a population density of about 35,000 people.

Solar mini-grids are an ideal alternative to grid electricity in remote villages that do not have grid connectivity. And because mini-grids are independent entities, they can also be controlled and managed without presenting threats to the conventional grid [7]. Such distributed energy systems also provide more reliable electricity, as any outages or interruptions to electricity supply can be quickly identified and corrected. Additionally, having the site of power generation closer to the load also reduces transmission and distribution losses.

Power transmission and distribution in rural areas of Kenya (arid and semi-arid) are currently constant but 
with a slow growth rate, hence lagging economic and social development in such areas with regard to vision 2030.

Generally this project work aims at helping the power generating and distributing companies to have alternative options for power generation for rural electrification program (REP) as they seek to increase the supply capacity and expand power connections to every household through both grid and off-grid systems hence proposal for a solar mini-grid development.

In the event of a needed back-up or an alternative supply to the region, a diesel generator is proposed to supply power to the region. This paper has three distinct objectives stated as follows:

- To evaluate the load power consumed by the rural village setting through analysis of possible loads contained per setting and estimating the consumption over a pre-determined period so as to serve as the base reference point for the capacity of the proposed mini-grid;

- To analyze and evaluate the load capacity requirements of the solar mini-grid through data comparison with the domestic load requirements of the total considered loads estimated to be covered by the solar mini-grid supply and optimize on the production capacity;

- To propose the development of a solar power mini-grid in the viable areas identified through simulation of the mini-grid using HOMER software to bring a real picture of the proposed model and also evaluate its economic value and viability.

\section{Climatic Data and Electric Loads Details}

Nanyuki is a market town in Laikipia County of Kenya lying north-west of Mount Kenya. It is situated just north of the Equator $\left(0^{\circ} 01^{\prime}\right.$ North). It covers an area of $9462 \mathrm{~km}^{2}$.

The region's climatic data can be best described by the data shown in Table 1. It is characterized by high daily solar irradiance values which make it suitable for solar power generation. The average daily solar irradiance is $5.53 \mathrm{KW} / \mathrm{m}^{2} /$ day but for accurate simulation data an average of the past four years was obtained and used in this case so as to be able to predict the trend for the coming years the project will be in operation [8] [9]. Similar data is also used in the simulations.

The data is also in comparison with existing information on rural electrification. This is done so as to reduce the disparity and improve on its accuracy which would allow for feasibility of the project during simulation and analysis.

The loads in each of the setting above differ due to the nature of application hence different appliances have been considered in relation to the setting, the bottom line being the actual power rating of each appliance was taken.

Table 1. Total daily average solar data for the past four years.

\begin{tabular}{|c|c|c|c|c|c|}
\hline 2010 & 2011 & 2012 & 2013 & Avrg. & \\
\hline January & 6.289 & 6.61 & 6.964 & 6.591 & 6.613 \\
\hline February & 6.403 & 7.07 & 6.847 & 7.136 & 6.864 \\
\hline March & 6.129 & 6.996 & 7.116 & 6.302 & 6.635 \\
\hline April & 6.076 & 6.491 & 5.764 & 6.024 & 6.088 \\
\hline May & 6.18 & 6.229 & 6.092 & 6.498 & 6.249 \\
\hline June & 5.84 & 5.943 & 5.906 & 5.631 & 5.83 \\
\hline July & 5.52 & 6.052 & 5.464 & 5.489 & 5.905 \\
\hline August & 5.78 & 6.054 & 5.8966 & 5.889 & 5.905 \\
\hline September & 6.67 & 6.386 & 6.686 & 6.674 & 6.604 \\
\hline October & 6.402 & 5.937 & 6.29 & 6.475 & 6.276 \\
\hline November & 5.681 & 5.58 & 5.788 & 5.31 & 5.589 \\
\hline December & 6.33 & 6.148 & 5.751 & 5.657 & 5.971 \\
\hline
\end{tabular}

Total Average $=6.1879 \mathrm{KW} \cdot \mathrm{h} / \mathrm{M}^{2} /$ day. 
For practical reasons, a complete village setting was taken which included households, a local school, dispensary and a shopping Centre. However in this paper and for feasible simulation purposes only the local dispensary and the school were considered.

Table 2 and Table 3 show the load consideration for the local school and the dispensary respectively. While Table 4 shows the total load distribution of village set up. Figure 1 is the global horizon irradiance of Nanyuki area while Figure 2 is the load curve profile for both the school and the dispensary.

Total generated power $=178.4 \mathrm{KW} \times 1.3=231.92 \mathrm{KW}$. Hence a whole number of $240 \mathrm{KW}$ was taken for a module.

\subsection{BP 3220 PV Module (220 Watts)}

The BP 3220 is an advanced polycrystalline solar module that incorporates anti-reflective coated cells and glass to generate more energy (more KW·h per $\mathrm{kWp}$ ). Table 5 shows the electrical characteristics of the module.

Table 2. Load distribution of the local school.

\begin{tabular}{cccccc}
\hline Load Type & Operation Time (Hours) & Power Rating (Watts) Total Number Total Power (Watts) & $\begin{array}{c}\text { Consumption in } \\
\text { Kilowatt-Hour }\end{array}$ \\
\hline $\begin{array}{c}\text { E.S Lamps } \\
\text { Incandescent Lamps } \\
\text { (Security) }\end{array}$ & 3 & 40 & 50 & 2000 & 6 \\
Desktop Computers & 12 & 60 & 5 & 300 & 3.6 \\
Printer & 8 & 150 & 4 & 600 & 4.8 \\
Photocopying Machine & 3 & 120 & 1 & 120 & 0.048 \\
Water Pump & 3 & 180 & 1 & 180 & 4.027 \\
Total & 4 & 1100 & & $\mathbf{5 0 4 0}$ \\
\hline
\end{tabular}

Table 3. Load distribution of the dispensary.

\begin{tabular}{|c|c|c|c|c|c|}
\hline Load Type & $\begin{array}{c}\text { Operation Time } \\
\text { (Hours) }\end{array}$ & Power Rating (Watts) & Total Number & Total Power (Watts) & $\begin{array}{l}\text { Consumption in } \\
\text { Kilowatt-Hour }\end{array}$ \\
\hline E.S Lamps & 18 & 40 & 18 & 720 & 12.96 \\
\hline Incandescent Lamps (Security) & 12 & 60 & 4 & 240 & 2.88 \\
\hline Desktop Computers & 8 & 150 & 1 & 150 & 1.2 \\
\hline Refrigeration & 24 & 300 & 1 & 300 & 7.2 \\
\hline Autoclave & 4 & 450 & 1 & 450 & 1.8 \\
\hline Medical Centrifuge & 4 & 100 & 1 & 100 & 0.4 \\
\hline Water Pump & 4 & 1100 & 1 & 1100 & 4.4 \\
\hline Total & & & & 3060 & \\
\hline
\end{tabular}

Table 4. Total load consideration of the village.

\begin{tabular}{ccc}
\hline & Total (KW) & Total KW·h/d \\
\hline Local Primary School & 5.04 & 36 \\
Local Dispensary & 3.06 & 25 \\
Households (50 Houses ) & 154.05 & 687 \\
Commercial Center & 16.258 & 193 \\
\hline
\end{tabular}

Total generated power $=178.4 \mathrm{KW} \times 1.3=231.92 \mathrm{KW}$. Hence a whole number of $240 \mathrm{KW}$ was taken for a module. 


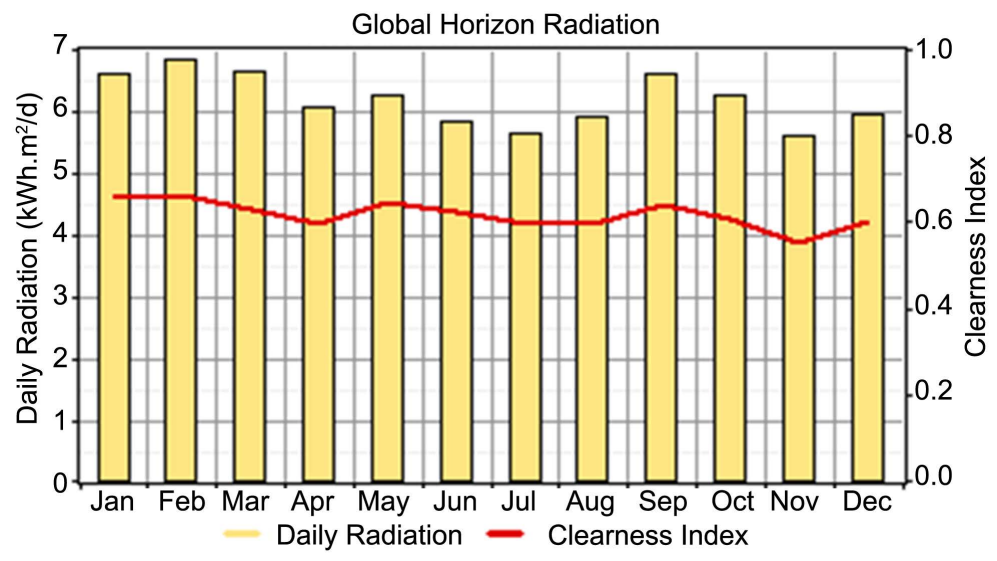

Figure 1. Global horizon irradiance of Nanyuki area.

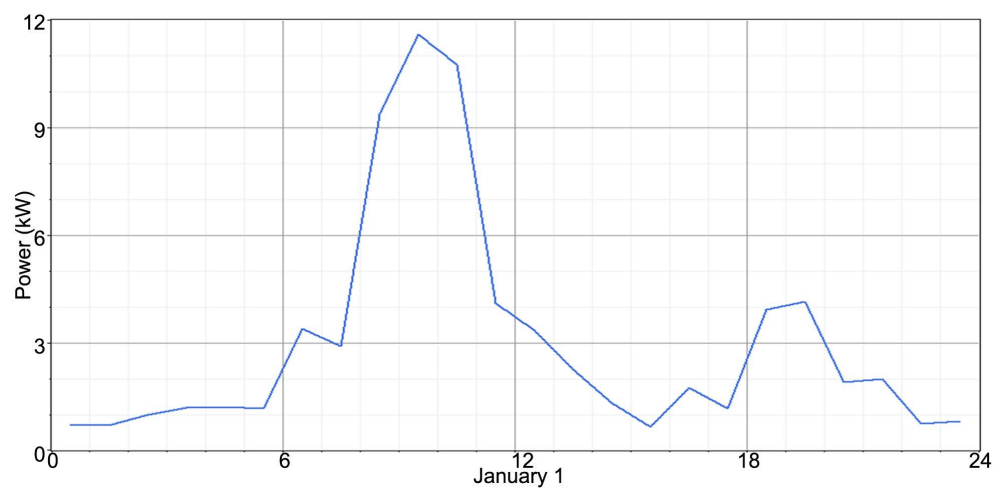

Figure 2. Load curve for the combined school plus dispensary.

Table 5. BP 3220 PV module (220 Watts).

\begin{tabular}{cc}
\hline Electrical Characteristics & Standard Test Conditions at $\mathbf{1 0 0 0 ~ W / \mathbf { M } ^ { 2 }}$ \\
\hline Maximum Power $\left(\mathrm{P}_{\max }\right)$ & $220 \mathrm{~W}$ \\
Voltage at MPP $\left(\mathrm{V}_{\mathrm{mpp}}\right)$ & $29.0 \mathrm{~V}$ \\
Current at MPP $\left(\mathrm{I}_{\mathrm{mpp}}\right)$ & $7.6 \mathrm{~A}$ \\
Nominal Voltage & $24 \mathrm{~V}$ \\
Short Circuit Current $\left(\mathrm{I}_{\mathrm{sc}}\right)$ & $8.4 \mathrm{~A}$ \\
Open Circuit Voltage $\left(\mathrm{V}_{\mathrm{oc}}\right)$ & $36.2 \mathrm{~V}$ \\
Efficiency at $1000 \mathrm{~W} / \mathrm{M}^{2}$ & $13.20 \%$ \\
\hline
\end{tabular}

The Mechanical characteristics of the BP 3220 PV module (220 Watts) are indicated below:

Solar cells 60 polycrystalline cells (each $156 \mathrm{~mm} \times 156 \mathrm{~mm}$ );

Dimensions $1.7 \mathrm{~m} \times 1.0 \mathrm{~m} \times 0.5 \mathrm{~m}$.

For the total number of panels required we calculate using the total array watt peak formula,

$$
W p=\frac{1.3 \mathrm{~W} \cdot \mathrm{h} \text { or } \mathrm{KW} \cdot \mathrm{h}}{\underline{\text { panel generation factor }}}
$$

where: $W p$-total array watt peak;

1.3-load loss allowance factor;

Panel generation factor-a value between 3 and 4 . 
Hence for this system the total $\mathrm{KW} \cdot \mathrm{h}$ per day is $36+25=61 \mathrm{KW} \cdot \mathrm{h}$

$$
\frac{1.361}{\underline{3.5}}=22.7 \mathrm{KWp}
$$

Hence to obtain the total number of solar panels we divide this value by the peak watt power of one panel, i.e. panel rating

$$
\frac{22.71000}{220}=104 \text { panels }
$$

The PV sizing of the system categories can be shown as follows:

For the system land sizing of the panels,

Each panel dimension $=1.7$ meters $\times 1.0$ meters

Panel area $=1.7 \mathrm{~m}^{2}$

Taking a spacing of $1 \mathrm{~m}$ for each panel $-1.7 \mathrm{~m}+1 \mathrm{~m}=2.7 \mathrm{~m}$

So each panel area $=2.7 \mathrm{~m}^{2}$

For 104 solar panels, total area is

$$
2.7 \mathrm{~m}^{2} \times 104=280.8 \mathrm{~m}^{2}
$$

Total required area $=280.8 \mathrm{~m}^{2}=0.07$ acres

Figure 3 shows an ideal monthly average electrical production of the system which commiserates to the irradiance of the region under study as shown earlier in Table 1. Figure 4 is the PV output of the system per year based on the irradiance received on the PV, while Figure 5 is the Homer software simulation model for the school and the dispensary.

\subsection{Battery Storage and Inverters}

The battery storage selected for this system are deep cycle batteries, Surrette 5000 series deep cycle-battery is chosen for this purpose. Electrical characteristics of this battery are shown in Table 6.

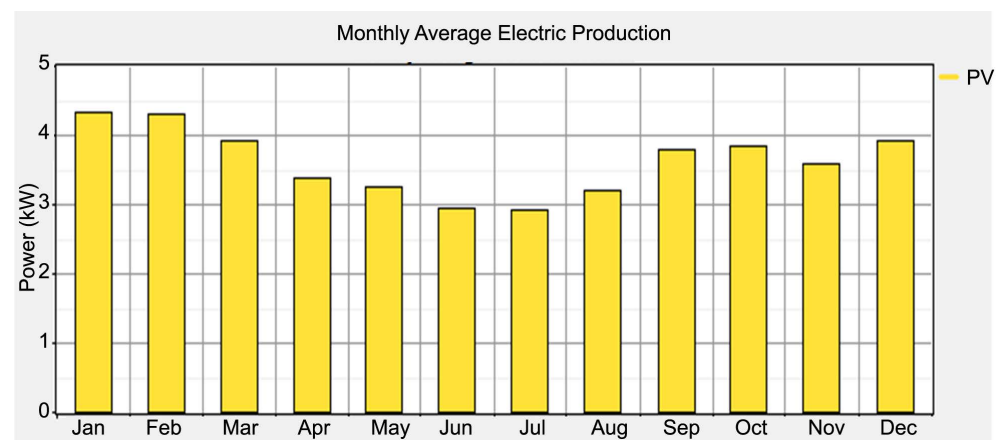

Figure 3. Monthly average electric production.

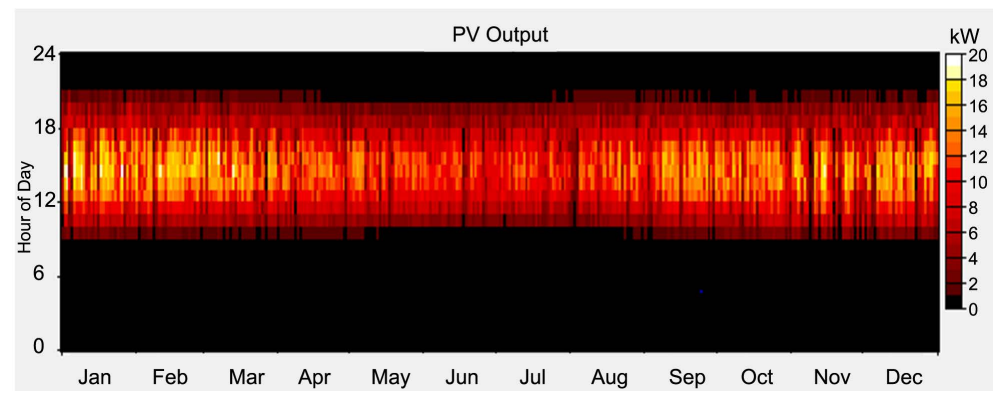

Figure 4. PV output of the system. 


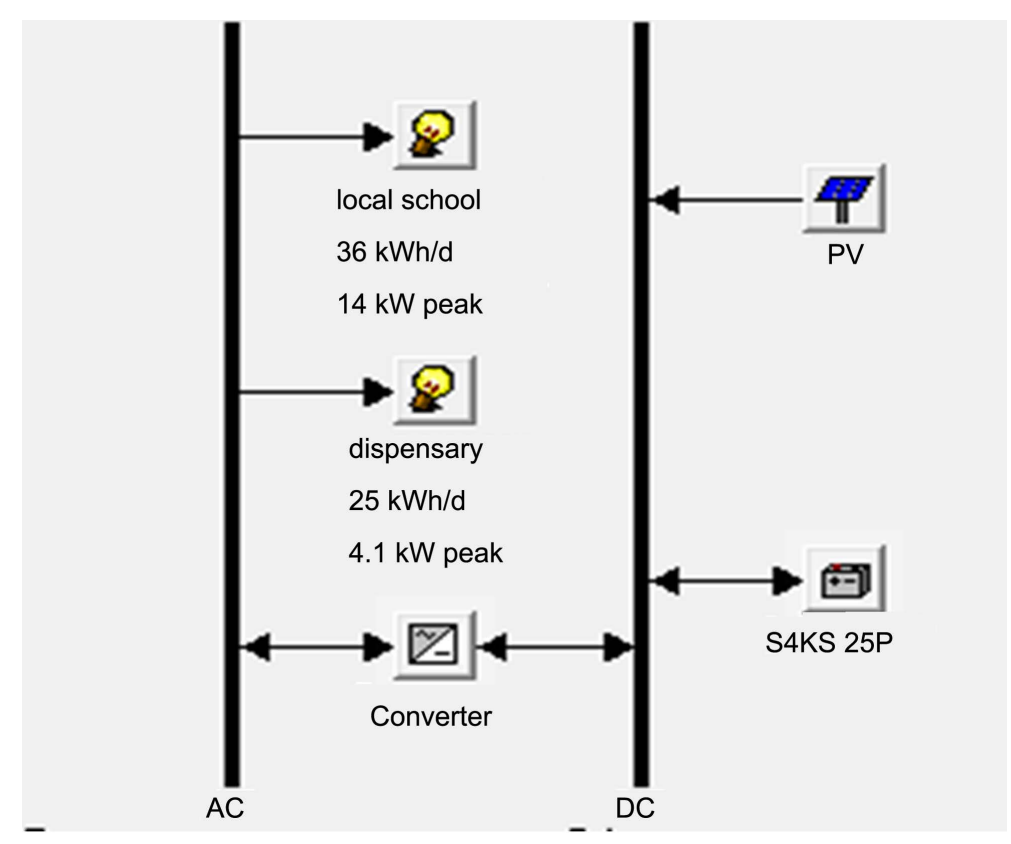

Figure 5. Simulation for the local school and dispensary.

Table 6. Battery characteristics.

\begin{tabular}{cc}
\hline Nominal Capacity & $1900 \mathrm{Ah}$ \\
Nominal Voltage & $4 \mathrm{~V}$ \\
Round trip Efficiency & $80 \%$ \\
Minimum State of Charge & $40 \%$ \\
Float Life & 15 Years \\
Maximum Charge Rate & $1 \mathrm{~A} / \mathrm{Ah}$ \\
Maximum Charge Current & $67.5 \mathrm{~A}$ \\
Lifetime Throughput & $10,569 \mathrm{KW} \cdot \mathrm{h}$ \\
Maximum Capacity & $1887 \mathrm{Ah}$ \\
\hline
\end{tabular}

The analysis of the battery calculation can be demonstrated as shown below from equation (4) to (6). For the dispensary plus the school (critical loads), their battery capacity is as shown below

The energy in the battery is $-18,211 \mathrm{KW} \cdot \mathrm{h} /$ year

Losses - $3541 \mathrm{KW} \cdot \mathrm{h} /$ year

$$
\text { Hence this gives a loss of } \frac{3541}{18211} \times 100=19.44 \%
$$

$$
\begin{aligned}
& \text { For the AH capacity, } \frac{61 \times 1000 \times 14}{0.85 \times 0.7 \times 4}=358,823.5 \mathrm{AH} \\
& \text { Total number of batteries }=\frac{358,823}{1900}=188.8=189
\end{aligned}
$$

$14=$ days of autonomy as from HOMER

$0.85=$ battery losses

$0.7=$ depth of discharge 
$4=$ Nominal battery voltage

In this system a central inverter system is adopted due to its simplicity in nature. Inverters are usually rated in VA and have a lifespan of 15 years with $75 \%$ efficiency. The inverter capacity is calculated as follows:

Total generated power $-8.1 \mathrm{KW}$, power factor of the system -0.8

\section{$8.1 / 0.8=10.125 \mathrm{kVA}=11 \mathrm{kVA}$}

So for the system an inverter capacity combination of $11 \mathrm{kVA}$ or more but with an output voltage of $240 \mathrm{~V}$.

Pan power inverters that are proposed, a DC to 3-phase AC power inverter that incorporates the characteristics shown in Table 7.

In the event of an emergency backup, a diesel generator may be provided. Figure 6 shows the model for the generator simulation. The simulation and analysis is as shown below. The generator capacity was rated $16 \mathrm{KW}$ which is the value similar to the peak load of this setting, hence the diesel generator capacity is; $16 \mathrm{KW} / 0.8=20$ $\mathrm{kVA}(0.8=$ power factor $)$. This shows that a generator capacity of $20 \mathrm{kVA}$ is required.

Figure 7 shows the plot of the AC load curve versus the generator output power. As depicted by the figure,

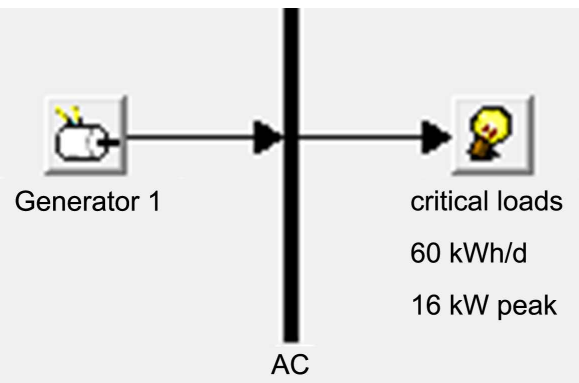

Figure 6. Simulation of the system with a diesel generator.

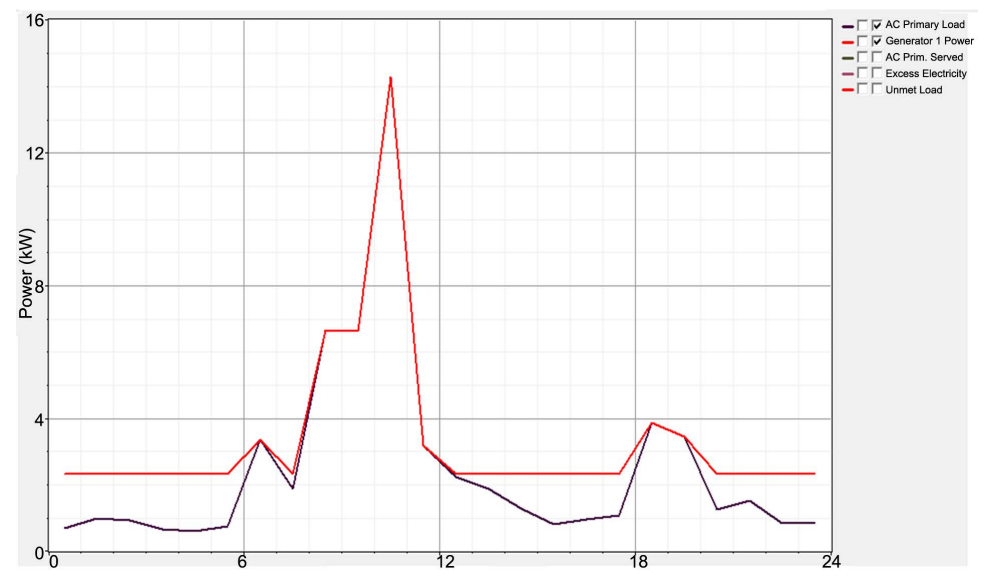

Figure 7. Shows the plot of the AC load curve (purple) versus the generator output power (red).

Table 7. Datasheet for pan power 3-phase inverter.

\begin{tabular}{cc}
\hline Output Power & $5 \mathrm{KW}-12 \mathrm{KW}$ \\
Output Frequency & $50 \mathrm{~Hz}$ \\
Input Voltage & $48 \mathrm{~V} \mathrm{DC}$ \\
Waveform & Pure Sine Wave \\
Maximum Efficiency & $80 \%$ (at $100 \%$ Load) \\
Power Factor & 0.8 \\
Battery & Lead-Acid Batteries \\
\hline
\end{tabular}


the system can be sustained using a diesel generator of $20 \mathrm{kVA}$. It is import to note that the generator is used for backup purposes. In other words it is only used when the Solar system is unable to supply the required power. Table 8 shows the various electric production ranges of generator output.

\section{Economic Analysis}

The economic analysis of the $20 \mathrm{kVA}$ mini-grid solar PV system was carried out to assess the cost and intended benefits of the project. It was carried out with the help of RET Screen software. The software is easy to use and has the capability of simulating the net present value and simple payback period as well as estimating the greenhouse gas saving potential of renewable energy projects over their entire operational life [10]. The NPV and simple payback period will help determine how feasible the project will be. The total investment cost comprises the following components; module, inverter, cables, mounting structures, engineering and project management, labour and miscellaneous costs. The costs of the various solar PV components used for this study were international estimates taken from renowned online solar PV research firms such as Solar buzz (solar market research and analysis), Solar Server (an online portal to solar energy) and Genentech Media Inc. [10]. The module and inverter cost alone makes up about $76 \%$ of the total investment cost. Table 8 contains a breakdown of the total investment cost. The total investment cost for the $20 \mathrm{kVA}$ project is estimated at US $\$ 1,200,000$. The economic analysis for this work was done by first developing a base case scenario consisting of the present electricity cost and other financial parameters. Subsequent scenarios were then developed from this base case to help analyze the implications of the various financing options on the project. Some of the options considered include grants/ capital subsidies, feed-in tariffs (FiT) and carbon credit financing. The parameters used to develop the base case include: It is interesting to note that, the base case scenario results in a simple payback period of about 10 years, which is more than twice the project life. However, applying a feed-in tariff scheme to the base case scenario indicates that it is possible for the project to be paid for within its lifetime with a feet-in tariff of about US $\$ 0.20 / \mathrm{KW} \cdot \mathrm{h}$ [11].

For the systems costs the following were the systems cost considerations. The cost are in US\$ but converted to Ksh at the exchange rate of 1 US $\$=85 \mathrm{Ksh}$

PV panel-1 Watt $=1.42$ US $\$=$ Ksh 120.00

Converter-3 KW $=1400$ US $\$=$ Ksh $119,000.00$

Battery -1 battery $=1250$ US $\$=$ Ksh 106,250.00

Generator-16 KW/20 kVA $=3000$ US $\$=$ Ksh 255,000.00

Hence the whole system cost is shown in Table 9. Note that the cabling and maintenance cost are taken as 20 and 15 percentage respectively of the total cost. In this paper, only the capital and replacement costs were considered leaving out the operation and maintenance since they vary with time considering the project duration hence difficult to predict future financial trends.

Table 8. The electric production and range of output of the generator.

\begin{tabular}{cc}
\hline Quantity & Value/Units \\
\hline Electrical Production & $29,310 \mathrm{KW} \cdot \mathrm{h} / \mathrm{yr}$ \\
Mean Electrical Output & $3.35 \mathrm{KW}$ \\
Min Electrical Output & $2.33 \mathrm{KW}$ \\
Max Electrical Output & $15.5 \mathrm{KW}$ \\
\hline
\end{tabular}

Table 9. System cost.

\begin{tabular}{cccc}
\hline Component & Capital Cost (US\$) & Replacement Cost (US\$) & Total Cost (US\$) \\
\hline PV Panel & 2160 & 2160 & 4320 \\
Converter & 793 & 793 & 1586 \\
Battery & 204 & 204 & 408 \\
Generator & 2550 & 2550 & 5100 \\
Overall System Costs & & & 11,414 \\
\hline
\end{tabular}




\section{Conclusion}

The draft procedure developed touches on some very important issues to be considered in the design of the regional-scale mini-grid connected solar PV systems using a solar field. Notable among these design steps are the assessment of the solar radiation data for the location, the identification and assessment of the size of the field used, selection of solar PV system components and finally, designing the layout of the mini-grid connected PV system. In designing the $20 \mathrm{kVA}$ grid-connected solar PV system for Nanyuki region in Kenya, the draft procedure developed was followed critically. A practical assessment of the various items was conducted and the lessons drawn from them used to update the draft procedure. At the end of the design of the $20 \mathrm{kVA}$ mini-grid connected PV system for Nanyuki region in Kenya, a standard procedure should be developed which can be used to design large-scale grid-connected solar PV systems. Analyses of the simulation results show that the project when implemented will supply about $61 \mathrm{KW} \cdot \mathrm{h}$ electricity per day or $22.2 \mathrm{MWh}$ annually, which is about $15 \%$ of Nanyuki annual electricity consumption. The project also stands the chance of saving about 200 tonnes of $\mathrm{CO}_{2}$ which will have been emitted by a crude oil fired thermal power plant generating the same amount of electricity. At the prevailing tariff conditions in the country, this project can be considered as financially viable with feed-in tariff scheme or other incentives such as grants/capital subsidies when applied. However, the other non-financial benefits like the greenhouse gas emissions savings can, in the long run, help mitigate the adverse effects of the climate change problem plaguing the entire earth. This project undertaking should be considered a preliminary study to the development of PV systems on mini-grids in the implementation of rural electrification program in Kenya and perhaps parallels can be drawn in other regions in the country with similar viable characteristics. This paper has offered general and overall focus on the primary design and operation considerations proving the viability of establishing a solar mini-grid in Nanyuki area. The HOMER simulations helped to paint the feasibility picture of the mini-grid component structure, which hence proved viable.

\section{References}

[1] Ministry of Energy Kenya (2011) Updated Least Cost Power Development Plan (LCPDP).

[2] International Energy Agency (2007) World Energy Outlook 2007. OECD/IEA, Paris.

[3] International Energy Agency (2009) How the Energy Sector Can Deliver on a Climate Agreement in Copenhagen: Special Early Excerpt of the World Energy Outlook 2009 for the Bangkok UNFCCC Meeting. OECD/IEA, Paris.

[4] Kennedy, S. (2011) Muzee Low Carbon Africa: Kenya.

[5] Kathambi, C.K. (2012) Kenya's Energy Demand and the Role of Nuclear Energy in Future Energy Generation Mix.

[6] Villalva, M.G., Gazoli, J.R., et al. (2009) Comprehensive Approach to Modeling and Simulation of Photovoltaic Arrays.

[7] Marissa, B.T., Raestad, J., Anderson, R.G. and Sainju, P. (2012) Rural Electrification: The Potential of Solar PV Off-Grid Systems, NORPLAN.

[8] Pidwirny, M. and Vranes, K. (2010) Solar Radiation. In: Cleveland, C.J., Ed., Encyclopaedia of Earth, Environmental Information Coalition, National Council for Science and the Environment, Washington DC.

[9] Pidwirny, M. and Walser, M.L. (2006) Earth-Sun Relationships and Insolation. In: Cleveland, C.J., Ed., Encyclopaedia of Earth, Environmental Information Coalition, National Council for Science and the Environment, Washington DC. http://www.eoearth.org/article/Earth-Sun_relationships_and insolation

[10] World Energy Council (2004) Renewable Energy Projects Handbook. World Energy Council, London.

[11] Vanek, F.M. and Albright, L.D. (2008) Energy Systems Engineering: Evaluation and Implementation. McGraw-Hill Companies, Inc., New York. 